\title{
THE DIVISION OF DIFFERENTIATED CELLS IN THE CENTRAL NERVOUS SYSTEM OF THE WHITE RAT.
}

\author{
By Alice Hamilton, M.D. \\ (From the Neurological Laboratory of the University of Chicago.) \\ With Platos XIX, XX.
}

Part I. Number and Position of the Dividing Cells.

The investigations which form the subject matter of this paper were undertaken in connection with a series of studies on the development of the central nervous system of the white rat, now being carried on in this laboratory.

At the outstart the question to be solved related only to the number and distribution of the dividing cells in the central nervous system of the new born white rat, but in the course of the investigation other problems suggested themselves and led to a study of the character of the dividing cells as well.

The white rat was chosen as material because of the abundant data relative to its development, which were already available in the laboratory, and also because of the immature condition of the nervous system at birth. The study was not, however, confined to the new born rat, although the investigations upon the animal at this stage were more extensive than those made upon earlier and later stages. Foetuses of about $17 \mathrm{~mm}$. in length ' were examined, and also rats $1,2,3$, and 4 days old.

The material was hardened in Graf's fluid, ${ }^{2}$ and in FLEM-

1 The aggregate weight of the 4 foetuses examined, was 3.09 g., each foetus being about $17 \mathrm{~mm}$. in length.

Oralic acid $8 a_{6}, 4$ rols.

Alc. 95\%, 3 voll.

Cbromic acid, $\% \%$ rols. 
MING's solution, the former giving the best results. It was imbedded in paraffin, and stained with iron-lack-haematoxylin, either alone or with erythrosin as a counter-stain, with saffranin and with toluidin blue and erythrosin. One series from the new-born rat was carried through by VignaL's method; i. e. alcohol-osmic acid hardening, picrocarminate of ammonia stain, -this method being said by VIGNAL to demonstrate the character of the cytoplasm and processes unusually well. Unfortunately it does not stain the mitotic figures, so that it was not of much value for this study, - except that it showed with great clearness the different forms of glia cells. GRAF's fluid and iron-lack-haematoxylin gave the most satisfactory results.

The cord and cerebral hemispheres of the new-born rat were first studied, and therefore the results obtained from them will be given first.

The cord of the new-born rat contained a large number of mitoses, which were found chiefly in the outer layers; the number on the ventricular surfaces was suprisingly small. In the brain the ventricular mitoses were more numerous than in the cord, but here also the extra-ventricular predominated. The brain and cord of the 24 -hour rat contained fewer mitoses than the new-born rat, while in the three days and four days old specimens the number secmed equal to that of the new-born. Comparing the foctus with these older specimens, a striking difference was seen, for here the mitoses seemed to be predominantly on the ventricular surfacts. Figs. 1, 2, 3, 4.

In order to decide the question beyond doubt the mitotic figures were counted in $I_{5}$ sections, $63 / 4 \mu$ in thickness, taken from the cerebral hemispheres and from the cervical, thoracic and lumbar regions of the cord of the new-born rat. Also from the cerebral hemispheres and lumbar cords of the foetus and of the 24-hours and four day specimens. The sections of the hemispheres were coronal and taken at the level of the chiasma. The following tables give the results of these counts. 
TABLE I.

The Number of Mitoses in 15 consecutive Sections, each Section $6.75 \mu$ in thickness, from the Brain and Spinal Cord of Rats at Different Stages of De. velopment.

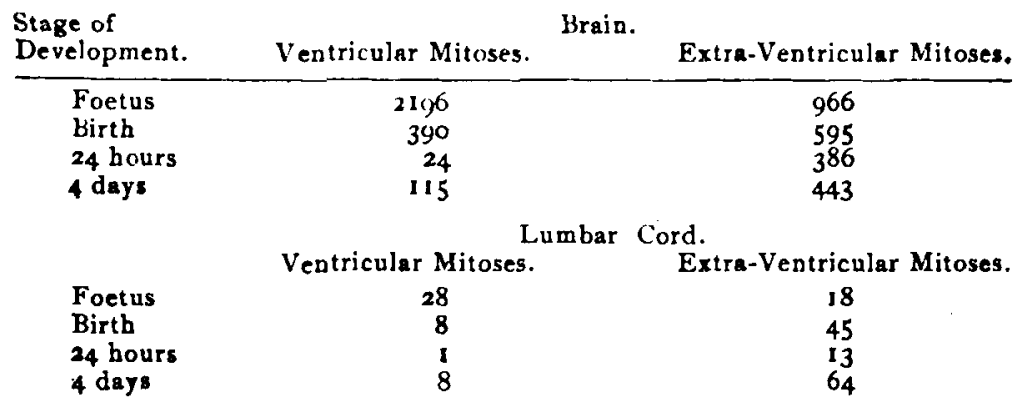

Cell division seems to reach its lowest ebb at the end of the first day. After this is slowly rises, until by the end of the fourth day, when the number of mitoses is not much behind that found at birth.

These tables show clearly the actual diminution in the mitoses as development proceeds, and the relative increase of the extra-ventricular mitoses over the ventricular. This relative increase reaches its height at the end of the first twenty-four hours, when the ventricular dividing cells are very few. After that there is an increase in mitoses in both regions, but slightly greater on the ventricular surfaces than in the outer layers. This relation of the numbers in the two regions may be seen in the following table:

TABLE II.

The Relative Number of Extra-Ventricular Mitoses Expressed as a Ratio. Based on the Observations on the Lumbar Cord given in Table I.

\begin{tabular}{lllc}
\multicolumn{2}{c}{ Ventricular. } & \multicolumn{2}{c}{ Lumbar Cord. } \\
\hline Foetus & 1 & to & 0.6 \\
Birth & I & to & 5.4 \\
24 hours & I & to & 13. \\
4 days & 1 & to & 8.
\end{tabular}

Although the actual number of mitotic figures varies appreciably in different animals from the same litter, which apparently are at constant stage of development, yet the proportion 
between the ventricular and the extra-ventricular mitoses remains practically constant for the same stages of growth.

A comparison between the different levels of the cord was made only in the case of the new-born rat.

TABLE III.

Observations Based on 15 Consecutive Sections, Each Section $63 / 4 \mu$ thick, from the Cervical, Thoracic and Lumbar Portions of the Cord of the NewBorn Rat.

\begin{tabular}{lcc} 
& \multicolumn{2}{c}{$\begin{array}{c}\text { Vord of New-Born Rat. } \\
\text { Extra-Ventricular. }\end{array}$} \\
\hline Cervical & 1 & 26 \\
Thoracie & 3 & 20 \\
Lumbar & 8 & 45
\end{tabular}

The lumbar cord resembles the cord of the foetus in the large number of mitoses, and in the relatively large number on the ventricular surfaces, while the thoracic cord shows a relative increase of extra-ventricular dividing cells, which is still more marked in the cervical cord.

From the lumbar cord in the same series, 25 sections were examined, in order to determine the exact distribution of the mitotic figures.

TABLE IV.

Showing the Distribution of Mitoses in the Lumbar Cord of the New-Born Rat, from Observations on 25 Consecutive Sections, each $61 \mu$ in Thickness.

l.umbar Cord of New-Born Rat.

$\begin{array}{lc}\text { Anterior gray column } & 61 \\ \text { Posterior gray column } & 25 \\ \text { Fiber tracts } & 8 \\ \text { Ependyma } & 10^{1}\end{array}$

In the distribution of the mitoses throughout the cord, the anterior horns of the gray matter seem to be the "seat of predilection" in the new-born rat, the posterior horns following far behind. No counts were made in the older specimens to determine the exact distribution, but judging from a careful examination, it is the anterior horns here also in which the greater number of mitoses are found.

1 This number is slightly smaller than would be expected from the examlnation of the 15 sections of the lumbar cord given above. 
This question as to the situation of the dividing cells and incidentally, the period up to which they persist in the central nervous system has been dealt with by Altmann (188I), RaUBer (1881 82-86), MERK (I 886), His (1886), VIGNal (1889), Schaper (1 897) and by Paton (1900).

Altmann ( $I$ ) was the first to point out the ventricular situation of the dividing cells and laid down the rule that in all organs of epithelial origin, cell division takes place on one surface only, that farthest removed from the mesoderm. His (2) confirmed this statement in his study of the human embryo of one month. RAUBER (3), on the contrary, denied any "seat of predilection" for the dividing cells. In his earlier publications he takes a more decided stand than in his later, but in all he insists that no layer of cells is exclusively the seat of cell division, and that the distribution of mitotic figures varies greatly, predominating now in the innermost layer, now in the outer layers. At one stage, for instance, in the spinal cord, the largest number is found in the anterior horns of the gray matter. His researches on frog embryos of $4.6 \mathrm{~mm}$. and of $15 \mathrm{~mm}$. show that at both these stages the ventricular mitoses predominate, but extra-ventricular ones always are present. He explains the apparently contradictory views held by different observers on the ground that the material used represented very different stages of development.

Merk (4) worked on embryos of fish, amphibia, birds and mammals, including rats. He upholds Altmans's view very strongly, and although he admits that scattered mitotic figures are in some instances found, yet those situated on the ventricular surfaces are always-in the cord and cerebral hemispheres - very much in the majority. An exception is found in the early stages of development in fish and amphibia, where for a short time, cell division is equally distributed in all layers. ${ }^{1}$ But in the higher vertebrates from the time of the closure of the

1 It is remarkable that Merk found the diffuse arrangement of the mitosea in the early stages, while moșt observers, as will be seen, find this, if at ell, in the later stages. 
medullary tube, up to the period represented by the 9 day chick, all mitotic figures in the cord are around the canal; all, with a very few exceptions, in the brain are around the ventricle. He counted the mitoses in 25 sections of both cerebral hemispheres of a mouse embryo, $2-3 \mathrm{~mm}$. in length and found 50 ventricular mitoses to 1 extra-ventricular. In the cerebellum and basal ganglia, however, he finds the mitoses always scattered and he considers that this fact is connected with the rapid growth of these parts of the central nervous system. Wherever growth is slow, as in the cord and hemispheres, cell division takes place around the ventricle, - wherever it is rapid, as in the cerebellum, thalamus and corpus striatum, cell division occurs in all layers of cells. This division of cells, he finds, ceases in birds and mammals at about the time when a posterior median fissure is clearly to be seen, or when the canal has become circular and the ependymal cells are provided with cilia.

VIGNal (5) takes a stand different from either of the above. He finds that in embryos of chicks, rabbits and sheep, the mitotic figures are only in the ependymal layer nearest the ventricle, but does not therefore conclude that cell division is confined to this region. On the contrary, he considers that the greater part of it takes place in the gray matter. He explains this apparent contradiction by assuming that these cells divide, not by mitoses, but by the formation of "achromatic figures." Naturally a description of such figures cannot be given, but as the nucleus, when dividing enlarges and loses some of its chromatin, the author considers that it is possible to distinguish the dividing cells from the resting ones. He is led to this belief by his failure to find mitotic figures in the developing cord anywhere except directly around the canal (although he treated his material by Flemming's method), and as there is every evidence of a more rapid increase in the number of cells than can be accounted for by the few ventricular mitoses, it follows that the cells must divide in some other way than that ususally described.

Schaper (6) confirms Altmann's dictum as to the ventricular predilection of mitoses, but only for the earlier stages of 
development, before the blood vessels have formed. He believes this to be true of all hollow organs lined with epithelium; cell division is at first most active on the surface lining the cavity, both because here the resistance is lessened and because, in all probability, the fluid in the cavity serves as nutrition for the new cells. Later on, however, when the development of the blood vessels has taken place and the nutrition is equalized, the extra-ventricular mitoses appear.

Paton (7), working on the brain of pig embryos, finds very few extra-ventricular mitoses and considers their occasional appearance a phenomenon of little importance.

The contradictory results obtained by these different authors may perhaps best be explained as RAUBER explained them, by the fact that they were obtained from embryos representing widely different stages of development. It may be that those who found cell division confined to the ventricular surfaces were studying much younger than those who found mitoses scattered through the gray and white matter. It is difficult to determine corresponding stages of development in different animals when only measurements are given, especially as in some instances the fresh, in others the hardened embryo is measured, but drawings of the cross sections of brain and cord make it possible to compare the stages with some degree of accuracy. Merk's drawings for instance, are most of them from quite early embryos, the germinating layer is very wide, the nerve cells immature, and therefore it is not remarkable that extra-ventricular mitoses were very few. One drawing of the cord, however (Fig. 5) and one of the brain (Fig. 2) shows a stage of development which is represented by the foetal rat in my series. In Merk's drawings the mitoses are seen to be confined to the ventricular surfaces-in the embryo rat in my series the ventricular mitoses predominate, but each section contains two or three dividing cells in the outer layers. Another drawing in MERk's article is from the cord of a $71 / 2$ day chick (Fig. 10) when the stage of development is about midway between the foetal and new-born rat in my series. Even here no extra-ventricular mitoses are shown. 
VIGNAL's results are still harder to bring into harmony with mine, for his illustrations show all periods of development from the long narrow tube with only the germinating layer of cells, to the fully formed cord with definite groups of multipolar cells, but throughout the series he finds not one extra-ventricular mitosis.

Although RaUBER himself suggests that the variation in number and position of the dividing cells is due to the period of development of the embryo in question, yet apparently he finds no difference between his frog embryo of $4 \mathrm{~mm}$. and the one of $15 \mathrm{~mm}$.

Paton gives drawings (see his Figs. 4 and 6) from pig em. bryos which correspond to the brain of the foetus and of the new-born in my series, but he finds very few extra-ventricular mitoses in either; only one is represented in his drawings. Even ScHAPER, although he mentions the appearance of these extraventricular dividing cells as coincident with the development of the blood-vessels, apparently does not attach much importance to them, as he gives no description of their number, nor of the exact areas in which they are found. There is no mention anywhere in the literature of dividing cells being found in the nerve fiber tracts.

It might be suggested that the grade of the animal in the zoological series is an important factor, that in the lower vertebrates the course of development is different from that in the higher, and this may be true, but so far there is not much in the literature to confirm it. His, working on early human em. bryos, arrives at the same conclusions as Merk, who uses embryos of fish, amphibia, birds and mammals.

Merk alone makes an absolutely definite statement as to the period at which cells cease to divide. According to him, the dividing cells gradually diminish in number and disappear by the time the central canal has become circular, the ependymal cells ciliated, and the posterior median fissure formed. This represents a stage which the cord of the white rat has attained at birth.

To recapitulate the points in which the results of this study 
of the central nervous system of the white rat differ from those arrived at by the observers quoted above:

Ist. The ventricular mitoses predominate only in the earlier stages of development, while the nerve fiber tracts are still very narrow, the layer of germinating cells wide and the nerve cells immature. Even at this stage, numerous extra-ventricular mitoses are found.

2nd. As development proceeds, there is a relative increase of extra-ventricular mitoses, so that by the end of the first day after birth, they are greatly in the majority. After this and up to the end of the 4 th day, there is a slight proportional increase of the ventricular mitoses again.

3rd. Cell division does not diminish steadily, but reaches a low point at the end of the Ist day and then rises again. This corresponds to the general suspension of growth in the whole animal just after birth and the gradual increase after that. The cells continue to multiply for at least four days after the stage described by MERK, and at the end of the fourth day the mitoses are more numerous than at the end of the first.

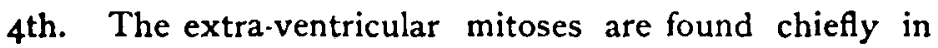
the gray matter, especially in the anterior horns, though a few are in the fiber tracts.

\section{Part II. Nature of the Dividing Cells.}

In the course of the determination of the number and persistence of mitoses in the central nervous system of the white rat, certain peculiarities in these dividing cells were noticed which led to a closer study of the nature of these cells found in the different localities. A brief examination of the cord at birth and for four days after birth is enough to convince one that the dividing cells are not all alike, that on the contrary, they differ in size and shape, in the character of the cytoplasm and in the thickness of the chromosomes. The variations in size are not so marked in the dividing cells of the brain as in the cord, but they are appreciable, and the other differences are as clearly marked as in the cord. In the brain and cord of the foetus the majority of the dividing cells are of one kind 
only, and at first sight one does not notice any striking difference, but a more careful study r.veals almost as many types of dividing cells here as in the later specimens. It will be more convenient to describe these cells as they are found in the different cell layers, rather than at the different stages of development, for the character of the dividing cells is very much the same in the corresponding localities in both early and late specimens.

Taking first the ependyma of the cord, we find that the great majority of the dividing cells are of the kind described by $\mathrm{H}_{\text {Is }}$ as germinal cells, - round or oval cells, measuring, in the white rat, from $7.5 \times 6 \mu$ to $12 \times 10.5 \mu$ (Fig. 5). These cells usually lie directly bordering on the canal, but in the cord of the foetus they may be the distance of one or two cell layers from the edge. In the cord after birth the germinal cells are usually smaller than in the foetus. These germinal cells form the majority of all dividing cells in the foetus and are found in appreciable numbers around the ventricles in the later specimens. They are found in all the stages of mitosis, but, except for the different arrangement of the chromosomes, they show no great variations. There are, however, occasionally dividing cells in the ependyma of the cord which cannot be classed with these typical germinal cells, but which differ greatly from them. These are long cells, much larger than the typical germinal cells of His, pointed at one or at both ends and in several instances sending a proces, to the internal limiting membrane of the canal (Figs. 6, 7), the cell shown in Fig. 6 measuring $24 \times 7.5 \mu$. These lorg pointed cells are situated always at the ventral and dorsal extremities of the canal, in the region of the ventral and dorsal plates of His, where, accord. ing to His, no neuroblasts are formed, the ventral plates becoming converted into neuroglia, the dorsal filled with spongioblasts. Certainly these cells are not the germinal cells of HIs, but resemble in cvery way, except their great size, the spongioblasts which are so abundant in these regions. It is interesting to note in this connection that, as the development of the cord proceeds, the dividing cells around the canal tend 
more and more to lie at the dorsal and ventral ends of the canal, at the points, in other words, where the spongioblasts persist after they have disappeared from the remainder of the ependyma. No such long pointed dividing cells are found in the ependyma of the brain, the mitoses here are all found in round or oval cells, and lie usually in the layer directly bordering on the ventricle. In the brain of the foetus the ependyma consists of many layers of cells, and it is not uncommon to find germinal cells at quite a distance from the ventricle, but in the brain of the new-born rat the ependyma is reduced to two layers, and the typical germinal cells, now much diminished in number, are tound only in these two layers.

The dividing cells in the gray matter of both cord and brain are more numerous in the later specimens, but the same types are found in all. It is here in the gray matter that the greatest variations are found; variations in the size of the nucleus and the character of the chromosomes, in the amount of cytoplasm and the shape of the cell-body. These cells may be roughly divided into two groups, those with no visible cell body, and those with a well developed cell body.

The cells of the first class are very numerous in the later specimens, more so than in the foetus. They are comparatively small, measuring about $6 \times 3 / 2$ (Fig. $8 \mathrm{~b}$ ), but even in the largest there is no visible cell-body, and the chromosomes are comparatively delicate (Figs. 8, 9, 10).

A much greater variety of cells belong the second class, the cells with a well developed cytoplasmic body. These are numerous in the gray matter of both cord and brain at birth and after, but less abundant in the foctal brain and cord. They therefore increase in number as the development of the gray matter proceeds. Their size varies from $10 \times 7 \mu$ (Fig. II, A) to $18 \times 12 \mu$ (Fig. 12, A). They are round or oval usually but may be pear shaped (Fig. I2) or spindle shaped (Fig. 13). The chromosomes are thick and heavy, the cytoplasm is granular, staining decply with saffranin or erythrosin, but often showing a clear zone around the nucleus. They lie among the neuroblasts in the foetal cord and brain and among the multi- 
polar and pyramidal cells in the later specimens, and may be found anywhere in the gray matter from the outer edge of the ependyma to the outer edge in the gray matter. A comparison of the size of these dividing cells with the large nerve cells in their immediate neighborhood gives the following results:

Dividing cell in the anterior horn of the spinal cord at birth (shown in Fig. 12) $18 \times 12 \mu$.

Multipolar cell (Fig. 12, B) $19 \times$ i $\mu$.

Dividing cell in cortex of brain at birth (Fig. 16, A) II $\times 8 \mu$.

Nerve cell (Fig. 16, B) I $2 \times 7 \mu$.

The size of these large dividing cells, therefore, corresponds very closely to that of the nerve cells in their neighborhood, while no other cell in the gray matter approaches them in size. The thin granular protoplasm staining deeply with erythrosin increases the resemblance to nerve cells.

In rare instances mitotic figures are found in cells which resemble in every way multipolar ganglion cells and which lie in the anterior horns of the gray matter in close proximity to the ganglion cells. Three such cells, from the three levels of the cord are shown in Figs. 18, I9 and 20. In Fig. 20 the chromosomes are not typical and the possibility of some degenerative change must be admitted, but the same cannot be said of those shown in Figs. 18 and 19 . Here the arrangement of the chromosomes is perfectly normal. In size, shape, processes and cytoplasm, these dividing cells resemble the multipolar cells in these regions. It is only in the cord that these dividing cells with processes are seen. The mitoses in the cortex of the brain are found in cells which are not as large as the largest dividing cells of the cord (Figs. 15, 16, 17), are usually round or oval and in no instance in this region was a cell with processes found undergoing division.

The nerve fiber tracts are narrow in the cord of the foetus and in the hemispheres where they form a very narrow layer between the wide ependyma and slightly narrower cortex (Figs. I and 3). At birth the tracts in the cord have increased appreciably both anteriorly and laterally while in the brain they 
form fully half the width of the section, the ependyma being reduced to a thin double layer. Within these tracts are found in the cord neuroglia cells of different sizes and, in the lateral tracts especially, scattered neuroblasts and multipolar cells. In the fiber tracts of the foetal brain there are, besides the neuroglia cells, many neuroblasts which are found lying diagonally and horizontally and vertically. Evidently the neuroblasts which are formed in the ependyma make a half revolution in this layer on their way to the cortical layer. Later stages show fewer neuroblasts, in the fiber tracts and finally-in the 4 days specimen-only neuroglia cells. The dividing cells in the white tracts are not very numerous at any stage of development, and when present they are usually of the same variety, without cytoplasm. Large ones are sometimes found in the anterior and lateral tracts of the cord, near the gray matter, but usually the mitotic figures are small and delicate.

It is evident that in the later stages of development the increase of cells in the central nervous system of the white rat does not take place through the division of one kind of cell only, that there is not an indifferent dividing cell, but several varieties of cells which may undergo division.

Referring to the literature on this subject one naturally begins with the classical work of His (2) on the central nervous system of the human embryo of one month.

According to $\mathrm{H}$ is the original epithelial elements which line the neural tube become differentiated into two kinds of cells, only one of which is capable of multiplication. These are the germinal cells which appear among the epithelial as round or oval bodies measuring in man $10 \times 14 \mu$. The nucleus is usually in one of the stages of mitosis, but when resting has a thick nuclear membrane and scattered chromatin masses. These germinal cells divide in the layers of ependyma nearest the ventricle, and their offspring migrate from this region out toward the periphery, grouping themselves together to form the layer of cells which His called the mantle layer. During their passage, or after completing it, they undergo changes which result in the formation of neuroblasts, that is, the oval cell be- 
comes pointed, the cytoplasm around the nuclcus forms a long process at the extremity of the cell which is turned toward the periphery. The nucleus also changes, the nuclear membrane becomes less thick, the chromatin masses more delicate and a nucleolus appears. These ncuroblasts never divide, neither do the supporting cells which constitute the second variety of cells found in the neural tube. They are long, narrow cells derived from the epithelium of the ependyma, which elongate and send out a process to the inner limiting membrane and another long branching process to the outer limiting membrane. These branching and anastomosing processes form the frame-work for the neuroblasts in the earlier stages, later on mesoblastic elements wander in and help to form the neuroglia. ${ }^{1}$ The original supporting cells, which $\mathrm{H}$ is called spongioblasts are in his opinion, incapable of division, and the increase in their number is not clearly explained inasmuch as he has never seen cpithelial cells dividing to form new spongioblasts, and thinks it doubtful whether any of the offspring of the germinal cells become spongioblasts. He observed what seemed to be mitoses in some spongioblasts but thought such appearances should be looked upon with great suspicion.

This description of the germinal cell and of the formation of neuroblasts is accepted by the majority of histologists, by von Költikek (8), by Ramón y Cajal ( 9 ), von Lenhossék (IO), Retzius (15), Kollman (11). The direct transformation of the epithelial cells of the surface of the body into germinal cells and of their offspring into neuroblasts, was observed by F LEXNER (I2) in Planaris torna. After removal of the head including the head ganglia the epithelial cells underwent mitotic division and the new cells wandered into the deeper tissues and passed through the stages described by His, resulting in the formation of neuroblasts with axones

On the question of the formation of the neuroglia, however, the original theory of $\mathrm{H}_{1}$ s has received little support and

\footnotetext{
1 This explanation of the mesoblastic origin of some of the neuroglia has been withdrawn by His in bis later papers.
} 
he himself has abandoned it. The mesoblastic origin of the neuroglia cells is rejected by almost all histologists, and as the number of ependymal cells is not nearly large enough to account for all these cells, it is usually assumed that they must increase by cell division. The germinal cell of His, then, is considered by the authors mentioned above as a simple epithelial cell in process of division. It is not in any sense a specialized cell and gives rise not only to nerve cells, but also to the cells of the neuroglia. On the question of the exact mode of formation of the supporting cells, there is a difference of opinion. Weigert (13) and Sala y Pons (14) both describe the gradual transformation of ependymal cells into glia cells as follows: The ependymal cell elongates and sends out two processes to end at the ventricle and at the periphery. Then by a gradual shortening of the peripheral process the cell is drawn out, away from the ventricle, it loses its connection first with the ventricle, then with the periphery, develops side processes and is converted into a spider cell. Von LenHossík (ro) accepts this description of the formation of glia cells for some of the cells, but only for a few, as the number of ependymal cells is too small to account for all the spider cells found in the adult cord. Some undoubtedly are formed in this way, but the larger number must arise by division of the cells of the neuroglia. Von Kölliker $(8)$ also thinks it probable that glia cells divide.

The explation of Vignal (5) differs from that of any other writer, not only by assuming a process of cell division which does not correspond with mitosis, nor amitosis as usually described, but also by denying any differentiation of cells in the central nervous system during the earlier stages of development. Thus, he considers not only the germinal cells indifferent, but all of the cells of the neural tube up to the time when a distinct grouping of the multipolar cells of the anterior horns can be seen. Until this time-a point represented by three and a half months in the human embryo--the cells have all been alike in spite of apparent differences in size, shape and staining reactions. Nerve cells, he maintains, cannot be distinguished from supporting cells until the dendrites are formed. 
SCHAPER $(6)$ has gone very exhaustively into this subject, and takes a stand midway between VIGNAL and the majority of observers. The original epithelial elements, according to ScHAPER, undergo one of two changes, either they are transformed to ependymal cells, which in higher vertebrates persist only around the ventricles, or they change to "indifferent" cells. As the ependymal cells are incapable of further multiplication, all increase in supporting cells and nerve cells must be through the division of these indifferent cells. At first these cells divide actively around the ventricles and the new cells wander out into the mantle layer. They are now the cells which by His were called neuroblasts, but Schapre considers them transition forms, not yet differentiated, capable of developing immediately in to either supporting cells or nerve cells, or of dividing again and again without losing their indifferent character. Later on the formation and division of germinal cells around the ventricle gradually lessens and these indifferent cells in the mantle layer begin to divide. We have now in the mantle layer three kinds of cells: first the true neuroblast, with a large clear nucleus, darker nucleolus and axone; second the glia cells, small with no visible cytoplasm, darker nuclcus with thick chromatin granules; third, larger cells with bubble-like nucleus, finely granular chromatin, no nucleolus and no visible cytoplasm. These last are the indifferent cells and are the only ones capable of multiplication. They persist up to a late period perhaps even into adult life, and it is by the division of these cells alone that nerve cells and also neuroglia cells are formed. In his description of the process of formation of the neuroblasts, SCHAPER follows His, but on the question of the. development of the neuroglia he is not quite so clear. Some of the cells are accounted for in the way given by Weigret and SALA y Pons, the migration and transformation of ependymal cells—others are formed by the division of the indifferent cells But SCHAPER says that it is hard to account for the enormous number found in the adult, as the fully formed neuroglia cells are incapable of dividing.

In a recent article Paton (7) elaborates this theory of 
Schaper. He too considers that the offspring of the germinal cells are indifferent, and may either develop into nerve cells or supporting cells or remain indifferent. PATON's work was on the brain of pig embryos. His description of the indifferent cells agrees with that of SсHApEk, but he finds them undergoing division almost invariably in the ependyma, not in the mantle layer. In all stages of development except the very early, Paton finds two kinds of germinal cells, one large with a well developed cell body, and one small with almost no cell body, but he thinks this difference is unimportant as both alike produce indifferent cells. Development procceds first in the ependyma which grows rapidly and is filled with germinal cells, indifferent cells and the spongioblasts of His. The indifferent cells which are to become neuroblasts pass to the outer layer of the ependyma, and here or in the nerve fiber layer are transformed into neuroblasts and pass out to form the cortical cell layer. As for the supporting cells, they are at first represented by the spongioblasts of His-transformed ependymal cells which diminish in size and number as they wander away from the ventricle, persisting in higher vertebrates around the ventricle only. As they disappear, the glia cells appear, being the result of division of the indifferent cells.

It is evident that there is nothing in the literature on the development of the central nervous system which points to the occurrence of large extra-ventricular dividing cells such as are found in the brain and cord of the white rat, nor does any theory of the process of cell formation allow for the presence of such cells.

The germinal cells of $\mathrm{His}_{\mathrm{s}}$ are described as always situated on the ventricular surface or separated from it by one layer of cells only. They have no large granular cytoplasmic body, and never have processes. SCHAPER has been already quoted as mentioning dividing cells in the gray matter, but these cells are, according to his description, invariably devoid of cytoplasm. Moreover, according to SCHAPER and to PATON, all of the new cells formed during the growth of the cord and brain are derived from the division of indifferent cells, which are of one 
type only, and it is impossible to tell whether nerve elements or supporting cells will result from the division of any cell. Fully formed neuroglia cells, spongrioblasts, neuroblasts and nerve cells are ail, according to these two authors, incapable of multiplication. There is indeed practically unanimous agreement among histologists as to the impossibility of the fully formed nerve cells or supporting cells dividing, under normal conditions, whatever may be true of pathological conditions. SCHAPER expresses the general view when he says: "A new formation of nerve cells in the fully developed nervous system is impossible for the division and increase of such highly differentiated ganglion cells as exist in vertebrates at least, must be rejected. Not only is a cell which is morphologically so highly differentiated incapable of dividing by karyokinesis, but it is impossible that a nervecell should suspend its physiological activity and with it that of a whole chain of neurones, during a period when the nuclear subsiance must be entirely devoted to the processes preparatory for cell division. Also during this period the nutrition of the processes especially the axone would suffer, and finally, an equal division of a cell can occur only when the whole cell body with all its protoplasmic contents takes equal parts in the division, and this in the case of a nerve cell, is of course, impossible" (p. 108).

Since the evidence is convincing that the axone is the first of the branches to grow off from the cell-body, the appearance of mitotic figures in cell bodics that exhibit dendrites would be open to one of two explanations only. First, that the mitotic appearances are not necessarily followed by a division of the cell-body; or, second, that the cell-body does divide after the axone has been formed. If this latter were true, then we might expect to find two cells attached to a single axone. Those who have worked most with the methods which would show this relation if it existed, have not observed it. The first hypothesis therefore, appears the more probable.

Putting aside, as rare and atypical, the dividing nerve-cells which are multipolar cells and the spongioblasts, which perlaps should not have much stress laid upon them, there still remains 
the large number of small and large cells which cannot possibly be classed together as undifferentiated descendants of the germinal cells, and which from the period of birth up to and possibly beyond the fourth day, form the majority of the cells concerned in the growth of the nervous system. That these cells are originally the offspring of the ventricular germinal cells of His seems most probable; that they have migrated into the outer layer by amocboid movements there is every evidence to show, for not only are they found in the white matter, but some of them in both gray and white are fixed in shapes which suggest that they have been through amoeboid changes. They are not, however, simply germinal cells which have migrated away from the ventricles, for they differ from the germinal cells in the character of their cytoplasm and in their size. The largest ventricular germinal cells measure in the cord $9 \times$ i $2 \mu$, the dividing cells of the gray matter up to $12 \times 18 \mu .^{2}$ The outline of the germinal cell is difficult to make out, the cytoplasm is clear, stains lightly; the outlines of the large dividing cells is distinct and the cytoplasm-the outer zone, at least-is granular and stains deeply with protoplasmic stains. Certainly these cells are not simply the germinal cells which have migrated from the ventricles, and if they are the offspring of the germinal cells, they have undergone some change before dividing for a second time; they have become at least partially differentiated. This will be seen more clearly if the dividing cells shown in the drawings from different regions be compared, those from the endyma, from the nerve fiber tracts and from the gray matter of the cord and the gray matter of the brain. If these cells are compared, it will readily be seen that in every instance the dividing cell tends to resemble in morphological character the resting cells in the region in which it is found. In the nerve fiber tracts the dividing cell is almost always small, narrow, with no apparent cell body-in other words it is like the neuroglia cell in these regions. Large dividing cells are rarely found in the fiber tracts, but in the cord

1 These measurements were not taken from the multipolar cells. 
they occasionally are found near the edge of the gray matter, and in the brain, especially in the earlier stages, they may be found among the ncuroblasts which are passing through the fiber tracts to the cortex. As for the large dividing cells which lie in the gray matter, they have an appreciable cell body, often quite as large as the nerve cells in those places, and it is noticeable that those found among the multipolar cells of the cord are as much larger than those in the cortex of the brain as the multipolar cells are larger than the pyramidal.

The obstacles to the assumption that fully formed nerve cells may divide are not only theoretical. Mitotic figures have been seen in the pyramidal cells of the cortex, in the neighborhood of an injury $;{ }^{1}$ but under normal conditions, in vertebrates at least, the division of nerve cells has never been seen, and even in the cases cited above, it may be that the presence of mitotic figures is not a proof that the cells really were dividing, but simply that the nucleus had entered upon the preliminary stages of mitosis which would never have been completed. To the division of the neuroglia cells there are no such strong objections; indeed, if the theory of WEIGERT is accepted as to the dissociation of the glia fibers from the cells, there secms no reason why these cells should not divide.

Assuming, then, that the large dividing cells of the gray matter are not either indifferent germinal cells, or fully differentiated nerve cells, what explanation remains? Might it be that they are not now in process of division but have already divided, and before the nucleus has returned to its resting condition, differentiation has proceeded and the cell is changing to a multipolar or a pyramidal cell ? To this it must be objected that during mitosis all the energies of the cell are absorbed in this process and a further differentiation never, so far as we know, takes place until this is completed.

It seems impossible to explain the different varieties of dividing cells in this animal except by assuming a process of

\footnotetext{
1 Cattani (16), Mondino (17), Friedman (18), Coen (19), Marinesco (20), Sanareli. (25), Vitzou (22), Tedeschi (23).
} 
cell multiplication for the later stages of development which is different from that of the earlier. In the earlicr stages, we find ventricular germinal cells dividing and their offipring gradually transformed to neuroblasts and supporting cells. In the later stages this process is replaced by the repeated division of immature neuroglia cells and immature nerve cells, which are undoubtedly specialized cells, but are not yet fully developed.

How long these cells retain their capacity for repeated division it is impossible to say, but apparently in the case of the white rat both kinds of cells continue to be capable of miotsis after the end of the $4^{\text {th }}$ day of extra-uterine life.

\section{Summary of Pant II.}

I. There are at least two kinds of dividing cells in the central nervous system of the white rat; one small, with no visible cell-body, the other large with a well developed cell-body.

2. The neuroglia cells are derived from the small dividing cells; the nerve cells from the large ones.

3. The dividing cells found in the gray matter and fibertracts of the brain and cord, are not indifferent cells, but are partly differentiated, and by their size, character of cell-body and nucleus and predominant distribution, it is possible to tell which are to be nerve cells and which supporting cells.

4. Mitotic figures are occasionally found in multipolar nerve cells and in sporgioblasts.

\section{LITERATURE.}

1. Altmann. Ueber embryonales Wachstum, Leipkig, 1881.

2. His, Wilh. Anatomie menschlichen Embryonen, Leifsig, 1880.

Die neuroblasten und deren Entstehung in embryonalen Mark. Abhancl. math. physikal Klasse konigl. Sachs. Ges. Wiss. XXVI.

3. Rauber. Ueber das Dickenwachsthum des Gehirns. Sitkun'sber. d. naturf. Gesellsch. su Leipzig, 1882.

Hoffmann-Rauber, Lehrbuch d. Anat. d. Menschen, II Bd. 2 Abth. Erlangen.

4. Merk, L. Die Mitosen im Centralnervensystem. Denkschr. d. mask. naturw. Klasse d. kaiserl. Akad. Wiss. LIII, Wien. 
5. Vignal, W. Developpement des Elements du Systeme nerveux Cerebrospinal. Paris, r8so.

6. Schapkr, A. Zur feineren Anatomie des Kleinhirns der Teleostier. Anat. Anz. Bd. VIII, I\$93.

Die morpholog. und histolog. Entwicklung des Kleinhirns der Teleostier. MJorpholog. Jahrb. Bd. XXI, 1894.

Die frühesten Differzierungsvorgärige im CentralDervensystem. Arch. f. Entwicklungsmechanik, Bd. V, Abih. I, I897.

7. Paton, S. The Histogenenis of the Cellular Elements of the Cerebral Cortex. Being paper XXVII in the "Contributions to the Science of Medicine by the Pupils of William II. Welch." Baltimore, igoo.

8. von Kölliker, A. Handbuch der Gewebelehre des Menschen, 6 Autl. Bd. II, 1893.

9. Ramón y Cajal, S. Textura del Sistema Nervioso. Madira, i8g9.

10. von Lenhossík, M. Der feinere Bau des Nervenkystems, 2 Aufl., 1895.

11. Kollmann, J. Lehrbuch d. Entwicklungsgeschichte des Menschen. lena, 1898 .

12. FleXNer, $S$. Regeneration of the Nervous System of Planaria torna. Journ. of Morph., Vol. XIV, No. 2, $18 y 8$.

13. Weigert, C. Beiträge z. Kenntniss der normalen menschlichen Neuroglia. Abhandl. a. Senckenbergschen naiurf. Ges. Frankfurt a.M. XIX, Itigs.

14. Sala y Pons, quoted by Weigert, op. cit.

15. Retzius, G. Zur Kenntniss des Centralnervensystems ron Aniphioxus lanceolatus. Biolog. Untersuch. II, 1891 .

16. Cartair. Sulla Fisiologia del gran Simpatico. Gazz. desli Osp. 1885.

Sull'accrescimento del sistema nervoso. Gazz. deg'li Osp. 1885 .

17. Mondivo. Giornale della R. Accall. di Tomno, 1885 .

Archivio delle sciene penali, Torino, 1886.

18. FriedmanN. Ueber progressive Verändercingen d. Cianglitngellen bei Eatzundungen. Arch.f. Psych. Bd. 13, 1838.

18. Corn. Ueber Heilung von Stichwunden des Gehirus. Liegler's betträ'c, Bd. II, 1888.

20. Marinesco. Sur le regeneration des cellules nerveux. Comples rendus de la Soc. de Biol. Mai, I 894 .

21. SANARELLI. I processi reparativi nel cervello e nel cervelletto. $K$. Accad. dei Lincei, 1891.

22. Vitzou, La neoformation descellules nerveuses dans le cerveau du singe. Paris, 1895.

23. Tenescht. Ziegler's Beiträge, is87, Bd. XXI. 


\section{Descriftion of Figures.}

All the sections are from the white rat.

Fig. 1. Cross.section of lumbar cord of foetus (Body length $17 \mathrm{~mm}$. ), showing distribution of mitoseg. Mulotic figures in black.

Fig. 2. Cross-section of lumbar cord of new-born rat, showing distribution of mitoses.

Fig. 3. Cross-section of cerebral hemisphere of foetus (Body length 17 mm.) showing (listribution of mitoses.

Fig. 4. Cross-section of cerebral hemisphere of new-born rat, showiag distribution of mitoses.

Fis. 5. Ependyma of foetal brain.

(a) Ventricular surfaces with germinal cells.

(b) Germinal cell at a distance from ventricle.

Fig. 6. Ependyma of lumbar cord of new-born rat.

(a) Typical germinal cells.

(b) Long pointed dividing cell in ventral plate.

Fig. 7. Ependyma of lumbar cord of foetus.

(a) Long dividing cell with process, in dorsal plate.

Fig. 8. Lumbar cord of new-born rat, anterior gray column.

(a) (b) dividing cells of ist class, delicate chromosomes, no appar. ent cell body.

Fig. 9. Cervical cord of new-born rat, lateral fiber tracts.

(a) small dividing cell of ist class.

Fig. ro. Brain of new-born rat, fiber tracts. Veatricular surface towards bottom of the figure.
(a) stnall dividing cell of ist class.
(b) neuroblasts turning.
(c) neurublasts which have finished their half revolution.

Fig. Ir. Cervical cord of new.born rat, anterior gray column.

(a) small,

(b) large dividing cell of and class, with thick chromosomes and granular cytoplasm.

Fig. 12. Cervical cord of new born rat, anterior gray column.
(a) large pointed dividing cell of the and class.
(b) multipolar nerve cell.

Fig. 13. Lunbar cord of four days rat, anterior gray column.

(a) Spindle shaped dividing cell of and class.

Fig. 14. Lumbar cord of new-born rat, posterior gray columa.

(a) Large dividing cell of 2 nd class in anaphase.

Fig. 15. Brain of foetus, cortical cell layer.

(a) pial surface.

(b) dividing cell of and class.

fig. 16. Brain of new-born rat, cortical cell layer.

(a) large dividing cell of $2 \mathrm{nil}$ class.

(b) pyramidal cell. 
Pig. 17. Brain of four days rat, cortical cell layer.

(a) large dividing cell of and class.

Fig. 18. Cervical cord of new-born rat, anterior gray column.

(a) multipolar cell with nucleus in prophase.

Fig. 19. Thoracic cord of new-born rat, enterior gray column. (a) multipolar cell with nucleus in prophase.

Fig. 20. Lumbar cord of new-born rat, anterior gray column. (a) multipolar cell with nucleus in prophase. 


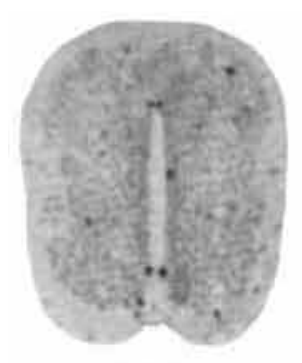

Fig 1

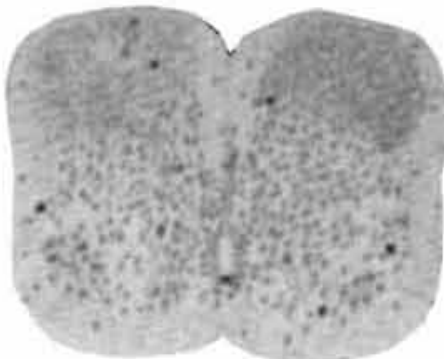

FIG. 2

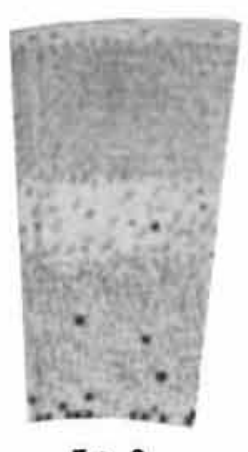

Fig. 3
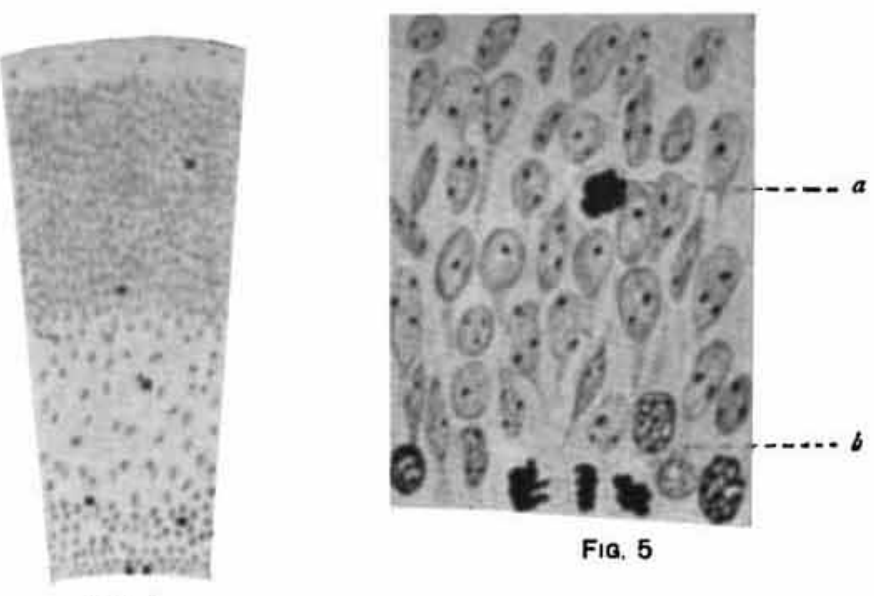

FIG. 4

FIG 11

FIG. 7
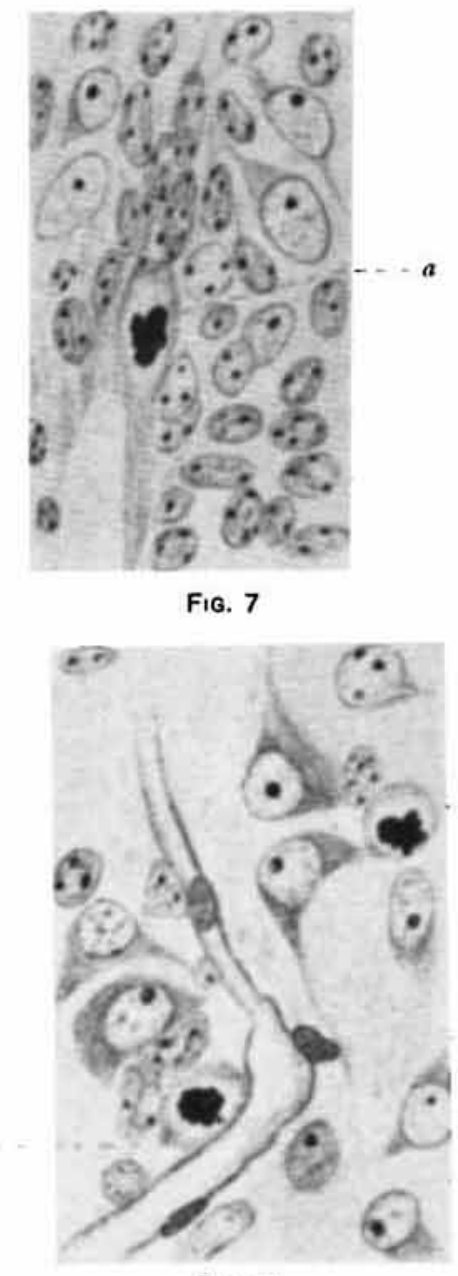

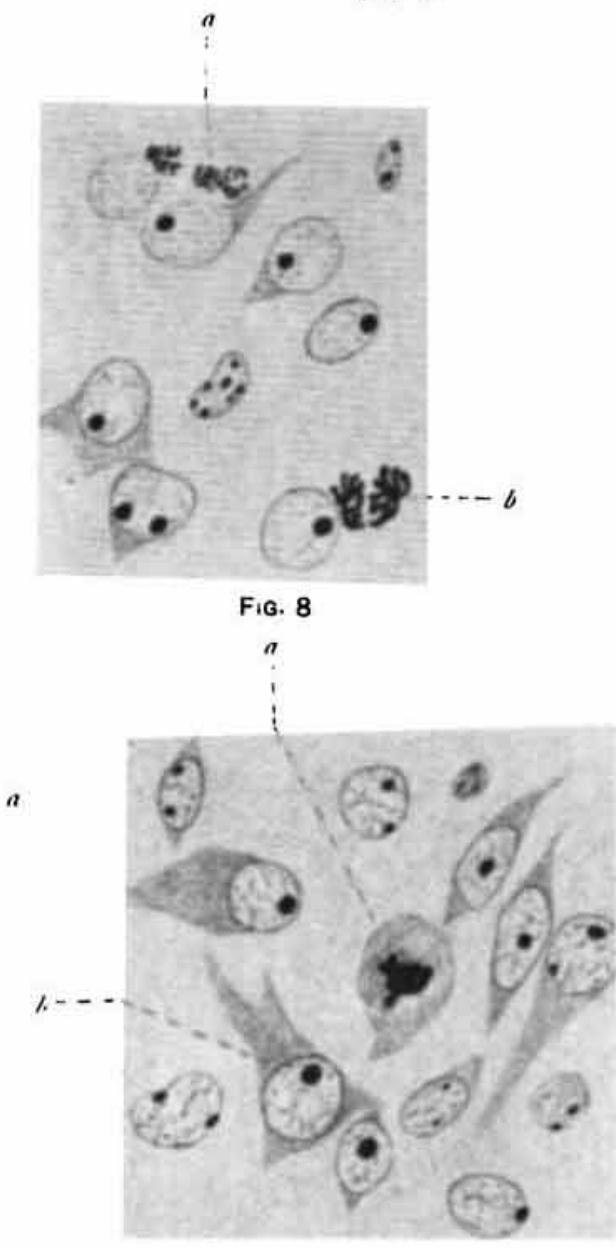

FIG. 12

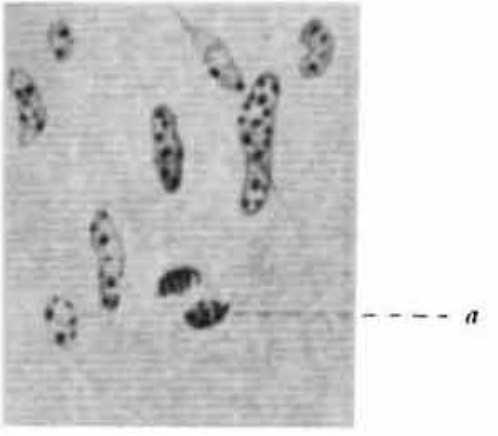

FIG. 9

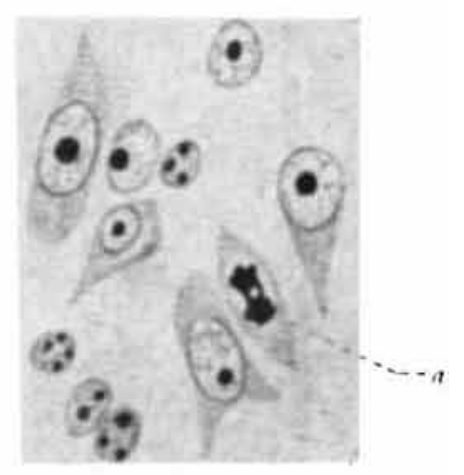

FIG. 13 

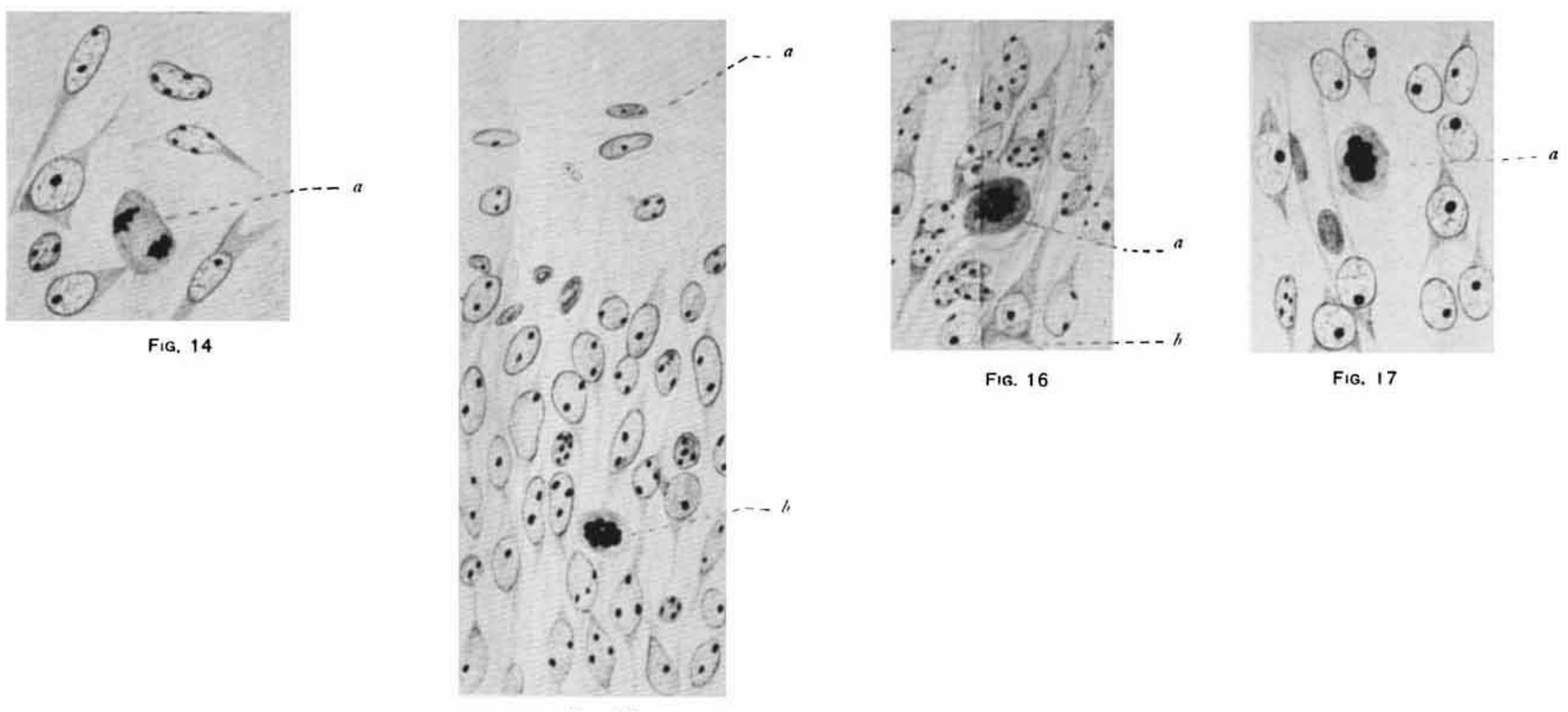

FIG. 15
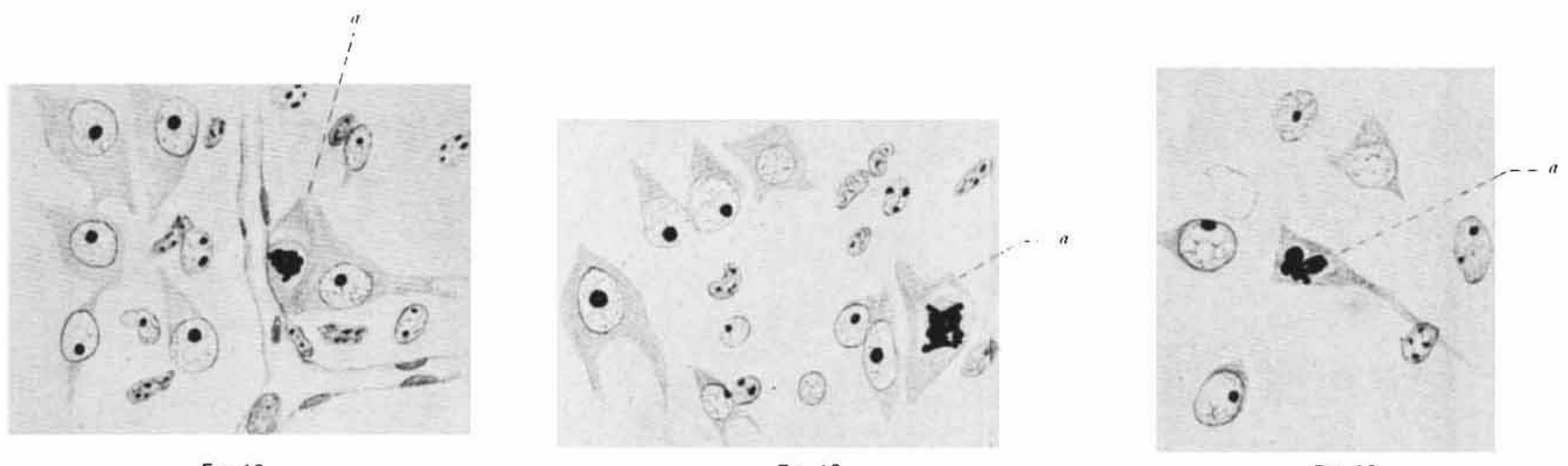

FIG. 18

FIG. 19

FIG. 20 